University of Wollongong

Research Online

Faculty of Social Sciences - Papers (Archive) Faculty of Arts, Social Sciences \& Humanities

$1-1-2019$

Understanding collaborative teacher teams as open systems for professional development

Kylie Lipscombe

University of Wollongong, klipscom@uow.edu.au

Kellie A. Buckley-Walker

University of Wollongong, kelliebw@uow.edu.au

Peter McNamara

University of Wollongong

Follow this and additional works at: https://ro.uow.edu.au/sspapers

Part of the Education Commons, and the Social and Behavioral Sciences Commons

Research Online is the open access institutional repository for the University of Wollongong. For further information contact the UOW Library: research-pubs@uow.edu.au 


\title{
Understanding collaborative teacher teams as open systems for professional development
}

\author{
Abstract \\ Teacher collaboration continues to be deeply grounded within effective professional development. \\ Teacher teams, where small groups of teachers work together in teaching and learning, have become \\ progressively more popular and are considered one of the most effective approaches to improvement and \\ growth. However, teacher teams are situated within a school system where interrelated sets of elements, \\ such as resources and priorities, interact and impact on their work. These interactions can both enable \\ and constrain the necessary conditions of members working effectively together but also their \\ capabilities in producing a meaningful impact on the school organization. As such, paying attention to \\ both the teacher team and the broader working environment of the school is important. Employing an \\ open systems framework, this paper explores the phenomenon of collaborative teacher teams by \\ examining them within the context of three primary schools in Australia. We propose a preliminary \\ framework for collaborative teacher teams as a useful lens to consider both the internal working \\ interactions of the team and how the site based professional development is influenced by and \\ transferred back into the school organization.
}

\section{Keywords}

teams, teacher, open, collaborative, development, systems, understanding, professional

\section{Disciplines}

Education | Social and Behavioral Sciences

\section{Publication Details}

Lipscombe, K., Buckley-Walker, K. \& McNamara, P. (2019). Understanding collaborative teacher teams as open systems for professional development. Professional Development in Education, Online First 1-18. 


\section{Understanding collaborative teacher teams as open systems for professional development}

Dr. Kylie Lipscombe, Dr. Kellie Buckley-Walker \& Dr. Peter McNamara

School of Education, Faculty of Social Sciences, University of Wollongong,

Wollongong, Australian

Kylie Lipscombe

University of Wollongong

Northfields Avenue, Wollongong

New South Wales, Australia, 2533

Email: klipscom@uow.edu.au

ORCID: 0000-0001-9433-7971

Peter McNamara

University of Wollongong

New South Wales, Australia, 2533

Email:pmcnamar@uow.edu.au
Kellie Buckley-Walker

University of Wollongong

Northfields Avenue, Wollongong

New South Wales, Australia, 2533

Email: kelliebw@uow.edu.au

ORCID: 0000-0002-4405-3345 


\section{Understanding collaborative teacher teams as complex yet effective open systems for staff development}

Teacher collaboration continues to be deeply grounded within effective professional development. Teacher teams, where small groups of teachers work together in teaching and learning, have become progressively more popular and are considered one of the most effective approaches to improvement and growth. However, teacher teams are situated within a school system where interrelated sets of elements, such as resources and priorities, interact and impact on their work. These interactions can both enable and constrain the necessary conditions of members working effectively together but also their capabilities in producing a meaningful impact on the school organization. As such, paying attention to both the teacher team and the broader working environment of the school is important. Employing an open systems framework, this paper explores the phenomenon of collaborative teacher teams by examining them within the context of three primary schools in Australia. We propose a preliminary framework for collaborative teacher teams as a useful lens to consider both the internal working interactions of the team and how the site based professional development is influenced by and transferred back into the school organization.

Keywords: collaboration; teacher teams; open systems; professional development; school leadership 


\section{Introduction}

An important direction of professional development in schools is the emphasis on intellectual capital, represented by the knowledge, expertise and experience of the school site. Teachers are a significant human resource, whose knowledge and performance of the school site, most importantly student learning and school priorities, advances school effectiveness. As such, there is an increased awareness for professional development at the school level, where teachers work together to develop their knowledge and understanding within the school site (Borko 2004, Kemmis et al. 2014). Different approaches to site based professional development are enacted in schools, most commonly through mentoring (Hobson et al. 2009, Grima-Farrell, 2015) coaching (Adams 2016, Kraft et al. 2018), and classroom observations (Hill \& Grossman 2013). Such approaches foster improved classroom pedagogies, leadership capacities, and student achievements (Stoll et al. 2011, Garza, Ovando \& O'Doherty 2016). These models of professional development are commonly dyadic one-to-one relationships. More collaborative approaches, such as professional learning communities (PLC) (Bolam et al. 2005) and communities of practice (CoP) (Wenger 1998, Brooks 2010) are gaining momentum in schools. These approaches extend the professional network phenomenon by fostering professional learning that is facilitated from multiple people all learning from one-another (Wenger 1998, Vescio, Ross \& Adams 2008) within a learning network (Mullen, 2000).

Collaboration is seen as an important component of professional development and the overall intellectual capital of the school. Harris, Jones and Huffman (2018) explain there are three collaborative models frequently adopted and researched in schools: (1) whole school model as an entire learning community that works with common norms and 
values (e.g., Hipp et al. 2008); (2) within school models where teams of teachers lead research and improvement (e.g., DuFour et al. 2007, Harris \& Jones 2010), and (3) across school models where collaborative activity occurs school to school (e.g., Stoll, Halbert \& Kaser 2011, Rempe-Gillen 2018). These studies provide important considerations for schools as they consider operating as collaborative communities.

This study is somewhat different in that the workings of a 'within schools' model of collaborative teacher teams is examined as a way of exploring how schools can consider how teams are situated within a whole school model. By doing this, collaborative teacher teams are considered as open systems because they interact with constantly changing inputs (such as students and policy); coordinate with many other throughputs or interactions in the school environment (such as other teachers); and, the outputs or activities of the team have an effect on all other parts of the school and ultimately school performance, namely teaching and learning. Ball and Forzani (2011) explain that too often there is a focus on the input, namely teacher quality, and then the output of student achievement without 'connecting the dots' (p. 17). Instead, through an open systems lens, this study attempts to connect the dots by responding to calls for research that theorizes the contexts and practical implications of collaborative teacher teams by examining conditions in situ within specific conditions of the particular context they work in (Bolam et al. 2005).

This paper firstly outlines an open system framework for teacher teams. This provides the theoretical tools to investigate collaborative teacher teams within an open system perspective. Secondly, the details of the study that provides the empirical foundation for the exploration of collaborative teacher teams as open systems are explained. Thirdly, the key findings related to the issues at hand are outlined. Finally, the 
significant implications of the emerging findings for the development and nurturing of collaborative teacher teams in schools within and beyond the team are discussed.

\section{An open system framework to collaborative teacher teamwork}

Open systems enable and promote interaction and change (Betts 1992) as well as the creation of new information whereas closed systems support the status quo. While schools are commonly referred to as open systems in the literature (Betts 1992, Bastedo 2006), the examination of teacher teams as open systems is less prominent. Teacher teams as open systems are important when considering site based professional development, as the context in which teacher learning is developed, provides a useful way of understanding how best to resource and support the professional development of teacher teams in schools.

Teacher teams as open systems obtain resources from the school environment, in which they operate, and transform them into outputs that are returned back to the environment in the form of products and services (Shermerhorn, Hunt \& Osborn 2002). In this way, the team, as an open system, works internally and considers the outside school environment as a way of understanding the consequences of their actions (Ahrweiler 2011).

\section{Inputs}

Information or resources from the school environment, known as inputs, are foundational to the consequential actions of the team (Hackman 1987). School leadership and policies are significant inputs to the way teams operate.

The input of leadership in establishing, influencing and nurturing collaboration in schools is well documented in the literature (Gumus, Bulut, \& Bellibas 2013, Szczesiul \& Huizenga 2014, Balyer, Karatas \& Alci 2015, Vanblaere \& Devos 2016). Leaders must 
ensure structure, such as organized time to meet (Tam, 2015) and ongoing support, monitoring is implemented to sustain the productive work of teams (Bolam et al. 2005, Dufour et al. 2007, Flanagan et al. 2016). Principals have been found to play a particular significant role in not only creating the necessary conditions of a collaborative culture (Murphy et al. 2009) but also providing opportunities for teachers with a designated team leader to work in self- managing teams focussed on teaching and learning (Mullen \& Hutinger 2008). Some studies have found that this leadership responsibility is difficult for principals with time and administration limitations (e.g., Balyer, Karatas, Alci 2015).

Policy is another significant input to teacher teams because it underpins education (Ozga, 1990) and exists in a context that reflects ideologies, beliefs and assumptions of the people in the school community (Armstrong, Belmont \& Verillon 2000). Ball (1994) explains that policy is a process rather than a product. This means that instead of being passive recipients, teachers must receive, interpret, recreate and implement policy according to the local environment in which they are situated (Bowe, Ball \& Gold 1992, Ball et al. 2011). This is of particular significance when considering teacher teams as open systems, as the context and conditions within which they work, both influence the way the policy, for example a curriculum syllabus, is received and interpreted, as well as the practices in which it is recreated and implemented.

\section{Throughputs}

While the inputs provide the foundations for long term group effectiveness (Schermerhorn, Hunt \& Osborn 2002), how members work together, often referred to as throughputs, include relational processes that achieve the common purpose of the team. Key throughputs from the literature include team member interactions with one another and trusting relationships. 
Team interactions contribute to the way members work together (Hoegl \& Gemuenden 2001, Robutti 2016, Stoll et al. 2006). Teachers generally welcome interactions focused on the sharing of ideas and resources yet find it challenging to engage in critical dialogue and inquiry of teacher practice (McLaughlin \& Talbert 2001, Borko 2004). Previous studies have identified the role of the team leader or coach can help build the capacity of team members to effectively interact with one another although many team leaders identify a lack of training and knowledge as a team leader (Becuwe et al. 2016, McKenney et al. 2016).

Team interactions, particularly complex dialogues such as problem solving and debate, require strong trusting relationships. Trust between team members can be developed when teachers are guided in conducting appropriate conversations, making decisions and managing conflict (Chatalalsingh \& Reeves 2014, Balyer et al. 2015). It is also affected by team members' confidence in each other's abilities (Donohoo, Hattie, \& Eells 2018). Trusting relationships in site based professional development, such as collaborative teacher teams, is particularly important as colleagues who work together regularly engage in critical dialogue and practice that examines teaching practice (Kemmis, McTagart \& Nixon 2014). According to Bryk and Schnedier (2003), developing and maintaining trust in such an environment is dependent on repeated social exchanges where words, commitments and actions are validated. For collaborative teacher teams, this means frequent meetings where action and commitments are identified and achieved.

\section{Outputs}

Outputs produced by teams will vary but usually include resources, teacher growth, informed decision making, team efficacy and satisfaction, and most importantly 
improved student achievement (Duyar 2013, Lofthouse \& Thomas 2017, Nolan \& Molla 2017). Improved teamwork has also been identified as a potential output of collaborative teams. This includes an increase in mutual willingness to support each other; open and reflective dialogue at meetings; and stronger emotional intelligence (Ohlsson 2013).

\section{The study: design and method}

The aim of this qualitative study was to examine how teacher teams interact as an open system as they engage in a common task, in this case, the development of common assessment tasks for their students. In schools, assessment is a common focus of teacher team work as it can directly impact on teaching and learning (Schneider, Egan, \& Julian 2013).

\section{Research sites and participants}

A purposeful sample was used in this study to select the school sites. Three key characteristics of the sample were: a school identified focus on teacher collaboration; a pre-existing team meeting structure; and, that the design of assessment tasks was a regular focus of team meetings. As such, the examination of teamwork across multiple sites allowed for diverse findings in consideration of different contexts but the generation of findings was aided by each team completing similar tasks.

Three primary school sites from New South Wales, Australia were selected as the locus of the study. The principal of each school volunteered their school for the study because of their current focus on developing teacher collaboration, as well as, growing the collaborative culture. Each principal discussed and then nominated teacher teams from each of their respective schools to participate in the study. Each nominated team was invited to participate in the study. 
Team A was from a school with 235 students. Teachers were released weekly in similar grade levels to work on planning curriculum and assessment in mathematics. This was a school focus as a result of recent schoolwide test results. The team of teachers participating in the study comprised of three Grade 2 teachers.

Team B was from a small school with 165 students. It was a single stream school (i.e. they only had one class in each grade level from Kindergarten to Grade 6). Teacher teams worked together in weekly staff meetings focusing on mathematics. They also met every third week with the infant team (Kindergarten to Grade 2) as well as the primary team (Grade 3-6). The primary team participated in this study. The team consisted of five teachers with multiple levels of experience.

Team C was from a larger primary school with 365 students. Mathematics was also a school priority. Teachers met approximately 3-4 times per term to design and plan mathematics teaching and assessment. The teacher team who participated in this study comprised of five teachers who taught Kindergarten to Grade 2. Two teachers taught Kindergarten, one teacher taught Grade 1 and two teachers taught Grade 2.

\section{Data collection}

Data was gathered from interviews, observations and artefact collection. Multiple data sources from the expertise of the educators as participants within their setting captured multiple realities of the phenomenon so the researchers could understand the practices and experiences of these experts rather than aiming to intervene and alter that practice (Kervin, Mantei \& Lipscombe 2015). Data included 26 interviews with individual teachers, 6 observations of team meetings and the collection of 29 artefacts (see Table 1).

Table 1: Schematic overview of collected data 


\begin{tabular}{llll}
\hline & Team A & Team B & Team C \\
\hline Team & Three Grade 2 & Five Grade 3-6 & Five Kindergarten \\
membership & teachers & teachers & to Grade 2 teachers
\end{tabular}

\begin{tabular}{|c|c|c|c|}
\hline \multirow{3}{*}{$\begin{array}{l}\text { Focus on team } \\
\text { meetings }\end{array}$} & Design of Grade 2 & Design of K- 2 & Design of Grade 3, \\
\hline & mathematics & mathematics & $4,5 / 6$ mathematics \\
\hline & assessment task & assessment task & assessment task \\
\hline Number of initial & 3 & 5 & 5 \\
\hline \multicolumn{4}{|l|}{ individual } \\
\hline \multicolumn{4}{|l|}{ interviews } \\
\hline Number of & $2 \times 60$ minutes & $1 \times 60$ minutes & $3 \times 60$ minutes \\
\hline \multicolumn{4}{|l|}{ observations of } \\
\hline team meetings & & & \\
\hline
\end{tabular}

\begin{tabular}{llll}
\hline Number of & 8 & 15 & 6
\end{tabular}

artefacts collected

\begin{tabular}{|c|c|c|c|}
\hline $\begin{array}{l}\text { Types of artefacts } \\
\text { collected }\end{array}$ & $\begin{array}{l}\text { - } \text { Curriculum } \\
\text { documents } \\
\text { - Assessment } \\
\text { tasks } \\
\text { - Meeting } \\
\text { minutes }\end{array}$ & $\begin{array}{l}\text { - } \text { Curriculum } \\
\text { documents } \\
\text { - Assessment } \\
\text { tasks }\end{array}$ & $\begin{array}{l}\text { - Curriculum } \\
\text { document } \\
\text { - Assessment } \\
\text { tasks } \\
\text { - Meeting minutes }\end{array}$ \\
\hline $\begin{array}{l}\text { Number of final } \\
\text { individual } \\
\text { meetings }\end{array}$ & 3 & $\begin{array}{l}4 * \\
\text { (*one member was } \\
\text { absent) }\end{array}$ & 5 \\
\hline
\end{tabular}


The initial interview took place at the beginning of the study with each individual teacher, in the three teacher teams, and was aimed at exploring the individual experiences and beliefs associated with teacher teamwork. Next, audio-visual recordings of team meetings took place. Each team chose the number and duration of team meetings to be recorded. This ensured the natural processes of teacher team meetings was acknowledged and was not impacted on by the research. Additionally, the researchers were not involved in the team meetings to lessen the impact on the teacher interactions. Instead, the recordings were designed to capture the normalised process of the team meetings. After the observations, all teachers were involved in a further individual interview to reflect on their experiences working in teams, including what factors enabled and constrained team work. Finally, artefacts from each teacher team were collected and examined to explore the resources used and designed.

\section{Data analysis}

Data was analysed in consideration of the open system framework of the study, specifically an adaption of the Schermerhorn, Hunt \& Osborn (2002) open system model. Data was analysed across two stages. Firstly, a deductive analysis using the open systems framework was carried out using three categories of inputs, throughputs and outputs. This initial analysis was completed by examining the interview, team meeting and artefact data and coding against each of the open system components. An inductive approach to coding was then used. Inductive analysis ensured a more analytical approach could be taken to data analysis to determine sub-themes and additional outliers that emerged from the data. To complete the inductive analysis, a spreadsheet was created to engage in further analysis of the deductive coding. Thirty-four sub themes initially emerged. A further analysis was completed to consider the overlap of these sub themes and to collapse similar 
subthemes into major themes. Eleven major themes emerged from this analysis (see Table

2).

Table 2: Data analysis codes and themes

\begin{tabular}{|l|c|c|c|c|}
\hline INPUTS & Purpose & Policies & Environment & Leadership \\
\hline School-wide expectations & $\mathrm{x}$ & & & \\
\hline Individual motivations & $\mathrm{x}$ & & & \\
\hline Principal & & & & $\mathrm{x}$ \\
\hline Physical environment & & & $\mathrm{x}$ & \\
\hline Technology & & $\mathrm{x}$ & & \\
\hline Curriculum documents & & & & \\
\hline Team goals & $\mathrm{x}$ & $\mathrm{x}$ & & \\
\hline Templates & & $\mathrm{x}$ & & \\
\hline Time & & & & \\
\hline Agenda & & $\mathrm{x}$ & & \\
\hline Minutes & & $\mathrm{x}$ & & \\
\hline Data spreadsheets & & & & \\
\hline Syllabus & & $\mathrm{x}$ & & \\
\hline Google docs & $\mathrm{x}$ & & & \\
\hline Shared beliefs & & & & \\
\hline Different beliefs & & & & \\
\hline Leadership led PD & & & & \\
\hline
\end{tabular}

\begin{tabular}{|l|c|c|c|}
\hline THROUGHPUTS & Facilitation & Interactions & Decision making \\
\hline Designated leader & $\mathrm{x}$ & $\mathrm{x}$ & \\
\hline Distinct team roles & $\mathrm{x}$ & $\mathrm{x}$ & \\
\hline Expert advice & & $\mathrm{x}$ & \\
\hline Focused task & & & $\mathrm{x}$ \\
\hline Paired versus team tasks & & $\mathrm{x}$ & $\mathrm{x}$ \\
\hline Interest based decisions & & $\mathrm{x}$ & $\mathrm{x}$ \\
\hline $\begin{array}{l}\text { Experienced based } \\
\text { decisions }\end{array}$ & & & $\mathrm{x}$ \\
\hline Shared voice & & & \\
\hline Disagreement & & & \\
\hline $\begin{array}{l}\text { Data informed decision } \\
\text { making }\end{array}$ & & & \\
\hline
\end{tabular}

This hybridised approach complemented the theoretical orientations of open

\begin{tabular}{|l|c|c|c|c|}
\hline OUTPUTS & Products & Knowledge & Collaboration & Students \\
\hline Task generated & $\mathrm{x}$ & & & \\
\hline Curriculum knowledge & & $\mathrm{x}$ & & \\
\hline Pedagogical knowledge & & $\mathrm{x}$ & & \\
\hline New resources used & & $\mathrm{x}$ & & \\
\hline $\begin{array}{l}\text { New ways of working } \\
\text { together }\end{array}$ & & & $\mathrm{x}$ & \\
\hline Team satisfaction & & & $\mathrm{x}$ & \\
\hline Student centred focus & & & & $\mathrm{x}$ \\
\hline
\end{tabular}

systems by allowing the tenets of the theoretical frame to be integral to the process of 
deductive analysis while allowing for themes to emerge directly from the data using inductive coding (Fereday \& Muir-Cochrane 2006). In this way a preliminary descriptive framework of teacher teamwork could be developed in consideration of open systems theory and the data and literature drawn from the study.

\section{Findings}

The three components of the open systems framework; inputs, throughputs and outputs are used to describe how three collaborative teacher teams interact as an open system. The intention is not to provide a comparative analysis across teams but instead to examine the various ways each team operated in consideration of the environment they worked within.

\section{Input}

In each of the teacher teams, inputs from the school environment included: an aligned purpose for collaborating; ongoing time; a dedicated space to meet; and curriculum mandates. These inputs were foundational to the actions of the team.

The aligned purpose of each team was to work together to improve mathematics at a school organizational level by collaborating with the same or similar grade level teachers on the mathematics curriculum and assessment conducive to their everyday work in the classroom. In all teams, the principal set the direction which was aligned to the school's strategic plan. One member of Team A explained that all teachers across the school recently worked together with the school principal to unpack the mathematics curriculum and then in teams they drafted learning continuums that were shared at the school level.

It was less clear how the school and team purpose was aligned in Team B and C. While both teams explained that mathematics was a school priority and teams were 
expected to focus their work to the field of mathematics teaching and learning, there was little data to show any significant connection between school and team work.

Dedicated time was a significant input facilitated by school principals that contributed to teamwork. Team A explained that the school principal organized weekly time 1 hour before school for each team to work together. One team member shared that it was imperative that time be 'spent on just one thing'. Team B explained that the principal also organized, regularly attended and contributed to team meetings which were usually held fortnightly before or after school for 20-30 minutes. At the request of team members, some additional time was given but often came at the cost of employing casual staff members. Teachers, in this team, explained that more time was needed if they were to 'produce products together at team meetings instead of after meetings'. Dedicated team meeting time was less structured in Team C, with teachers meeting 3-4 times per school term, depending on other school priorities. Most team members felt that more regular time was required if products were to be collaboratively developed. This was evident in observations where the completion of tasks was often not achieved.

Each team had a designated meeting space. Team A met in a school meeting room with furniture arranged conducive to group discussion. Team B met in the school library. This space offered a way for the team to sit together away from the classrooms and to use a large screen SMART TV to view shared documents during team meetings. Team C did not have a designated meeting space and instead met at multiple locations such as a classroom, library or staffroom, depending on availability. Two members of the team commented that the library was the most effective space particularly when other teams were also present. The team facilitator explained 'we are all in one area... we all collaborate in our own area... but we can go over to other teams to ask and share ideas'. 
Mandated curriculum policies from the curriculum authority were identified as significant inputs to teamwork. Team A used the mathematics syllabus as the focus of the meeting to validate and clarify ideas being shared between teachers at the meeting. Team B also planned on using the mathematics syllabus with the facilitator ensuring it was available on the enlarged SMART screen for team members, however observational data revealed it was not used. Instead the facilitator shared 'I think if you're happy to design the assessment after the meeting, the next time we meet, we might be able to just crosscheck with the syllabus and make sure we're going to have enough information". Data from Team $\mathrm{C}$ indicated that curriculum policies were used sparingly, with one team member referring to it once to clarify different outcomes between school year levels.

\section{Throughputs}

Team facilitation, team cohesion and collective decision making emerged as the significant throughputs of collaborative teacher teams.

All teams had a designated member as team facilitator. The team facilitators for Team A and B were determined by the principal and consisted of executive staff members. The facilitator of Team $\mathrm{C}$ was a younger member of the staff who volunteered to facilitate the team. She had no other leadership responsibilities at the school, however her grade partner, who was also in the team, was an executive staff member who she 'looked up to'. In the observations of team meetings, the facilitator of Team A and B had a clear approach to their role.

Team A facilitator was often observed asking questions of team members to support reflection and clarification. For example, 'how do we want to go about doing that?' and 'are you happy with this decision?' resulted in team members contributing ideas and solving problems together. In the initial interview she explained her conscious decision to apply this approach and the difficulties she had with it, sharing 'I've got to be 
really careful too that $\mathrm{I}$, as a facilitator, actually let people have their say and again, because of the knowledge that you already have of an area, it's hard when people don't actually have the same level of content knowledge'. It was evident, that the facilitator was balancing employing a collaborative approach with leading the team as an expert in the mathematics curriculum. One team member explained 'I would look to her leadership, because of her expertise in the area'.

Team B facilitator also purposefully applied a facilitated approach. He started the meeting by setting the focus and distributing resources to support the assessment design. He was observed paraphrasing team members' ideas, which aided in summing up and linking ideas between team members and on three occasions re-focused the group discussions when they got off track. He was not drawn on as an expert in the assessment design. During the interview he explained that he saw his role as a shared approach and team members 'lead each-other'.

Team $\mathrm{C}$ facilitator took a less obvious approach to facilitation. During the initial interview she explained 'I feel like because everyone is so open to collaborating and speaking up and being involved, especially when we've got team members that are so experienced, I don't really feel like I have to do all of that much'. During observation it appeared that the executive staff member in Team $\mathrm{C}$, who was not the designated team facilitator, was viewed as the expert in the team as she was often seen to make decisions and provide advice.

Team cohesion, in particular the degree in which team members could find purpose in working together, contributed to team interactions and productivity. Team A consisted of three members who taught the same grade level. Throughout two one-hour meetings, all team members worked together on the one task and at the conclusion of two meetings a completed assessment task and rubric was developed ready to implement. 
Team B met once for one hour. Team members taught across multiple but consecutive grade levels $(3,4,5 \& 6)$. Because of the diversity of team members, working together on the one product, as Team A did, did not eventuate. Teachers instead spent the time discussing and agreeing on the format and timing of the assessment task and sharing ideas on possible types of tasks that could be used in the assessment product. Grade 5 and 6 teachers then worked on the design of their task together at a later date and Grade 3 and 4 teachers designed their own tasks respectively. Team members commented on the usefulness of coming together to plan an assessment task, for example, 'it was good because we had the same goal and we really spoke a lot about what we wanted to get from it. We all knew where we needed to be...it's made us more aware that we can work together and have a similar form of assessment'. While this appreciation of planning together was consistent from all team members, the final assessment products designed were three very different tasks. It seemed that team cohesion was achieved by planning ideas and the sharing of resources rather than the actual design of an assessment task.

Team $\mathrm{C}$ also had five members who taught across multiple but consecutive grade levels (Kindergarten, $1 \& 2$ ). Over three one-hour meetings they worked together to discuss the skills and knowledge students required from Kindergarten to Grade 2 in a specific mathematics unit. Team meeting 1 and 2 predominately focused on discussing ideas together, whereas in meeting 3 team members largely worked in pairs or individually to begin drafting ideas for their assessment task. While the assessment tasks were not completed by the end of the three meetings, they were later designed individually or in pairs and placed on a school server for all teachers to access.

Collective decision making was common in all teams. Examination of team meetings in Team A revealed decisions were predominately made by the team facilitator and then agreed upon by team members. For example: 
Leader: I've got some other resources that I thought would be really helpful for us

Team member 1: I like this

Leader: What I really liked about this was that they align to the continuum

Team member 2: Yes, let's use these we need to be able to plot them

Further, most decisions in Team A were based on the likes and interests of team members. When ideas were suggested, responses were agreed upon with statements such as 'yes I like that' or 'I think it's great'. At times, past assessment tasks or the curriculum syllabus were used to help decide on the assessment design. Team B didn't make as many decisions as Team A as their meeting time was more focused on sharing ideas and not actually developing a task. Instead, ideas were put forward by team members but not necessarily agreed to. For example, a team member shared a technology resource he used previously as a platform for assessment. One team member commented that she thought it 'was a great idea', however, the other members did not comment. This platform was used by half of the team with other team members choosing different formats. This was also the case for Team C, where ideas on the type of assessment task were discussed, with no consensus reached. This was particularly evident when the Kindergarten and Year 2 team produced a pre and post assessment task while the Year 1 team designed only a post assessment task.

There was only one disagreement across all team meetings that led to a different solution. In the second meeting, one team member from Team A shared, what she believed was the aim of an assessment question. The team facilitator and another team member disagreed and justified their interpretation based on their beliefs. This discussion 
lead to the team agreeing to a different solution.

\section{Outputs}

Outputs were centered on assessment products; newly formed knowledge in mathematics curriculum; and collaborative team skills.

All teams worked on developing products such as assessment tasks and rubrics. Team A completed these products in team meetings while Team B and C completed the products after the meeting/s as a result of ideas shared at the team meetings. All teams discussed that the products developed should be placed on shared online servers for all teaching staff to access. Team A explained that this enabled teachers to consider how different grades have designed assessments tasks. It also helped school leaders monitor the types of assessments being implemented in the school.

Newly formed knowledge, in association with mathematics curriculum and assessment which resulted from teamwork, was identified in all teams. Team A facilitator explained that sharing and questioning each-other's ideas provided a way to break down curriculum requirements to discrete skills so that assessment tasks diagnosed student learning more effectively. This, she commented, had not been done before and was a direct result of the team collaboration. She also explained that this process will be utilized in future assessment design. Two members from Team B described that teamwork enabled them to learn a new way of assessment, specifically using 'brainstorming' as a formal assessment technique to measure student learning. One team member from this team also indicated that sharing her teaching practices and ideas with colleagues involved high levels of self-reflection, and as a result, she explained she was 'a better teacher'. Team $\mathrm{C}$ members shared that team conversations lead to "new ways of assessing from traditional methods', 'greater risk taking and innovation' and greater 'familiarity of curriculum content'. One member explained she 'never has understood the curriculum as 
much as now' due to constant team discussions focused on teaching and learning. While these new learnings are self-identified and based on perceptions data, they indicate a high level of team satisfaction in the team learning process with identified new learnings that have the ability to impact on the school organization.

Working together also appeared to improve other collaborative skills. Attentive listening and increased levels of trust in one another were identified as newly formed skills team members developed in Team A. Team B shared that increased risk taking and innovation were slowly being developed where members were more open to testing new ideas in their classrooms. The team facilitator identified that 'reflection on effectiveness' was a skill that required greater development, explaining 'we need to talk more about what we learn from working together'. Team $\mathrm{C}$ did not identify any newly acquired team skills although they did identify areas that they would like to develop further. These areas included staying task focussed, utilising agreed upon ways of working from team members to help facilitate collaboration and being more effective at producing products in team meetings.

\section{Discussion and implications}

In this section the inputs, outputs and throughput elements identified that enabled the work of collaborative teacher teams are discussed. These elements are unpacked in the context of how a collaborative teacher team interacts as an open system as they engage in site based professional development, in this case, the task of developing common assessment tasks for their students.

\section{Input elements}

The collaborative teacher teams in this study drew on four key inputs from the school environment: transformative shared purpose; working environment; policies and 
guidelines; and school leadership. Each of the elements is defined in Table 3 and elaborated on below.

Table 3: Input elements of Collaborative Teacher Teams

\begin{tabular}{|c|c|c|}
\hline Input Element & Definition & Example from study \\
\hline purpose & $\begin{array}{l}\text { A symbiotic relationship } \\
\text { between a team's purpose } \\
\text { and the purpose of the } \\
\text { organization within which it } \\
\text { operates leads to } \\
\text { transformative } \\
\text { directly related to teacher } \\
\text { and student learning }\end{array}$ & $\begin{array}{l}\text { Team A discussed how } \\
\text { assessment was a school and } \\
\text { team focus and as such teams } \\
\text { designed documents that } \\
\text { were utilized and adjusted at } \\
\text { the team level but with whole } \\
\text { school alignment and } \\
\text { contributions }\end{array}$ \\
\hline Working environment & $\begin{array}{l}\text { Factors such as time (e.g., } \\
\text { scheduled meeting times) } \\
\text { and space (e.g., meeting } \\
\text { places) that contribute to the } \\
\text { way teacher teams work } \\
\text { productively together }\end{array}$ & $\begin{array}{l}\text { All teams explained the } \\
\text { significance of frequent } \\
\text { meetings times and a } \\
\text { dedicated meeting space that } \\
\text { was conducive to team } \\
\text { conversations is required }\end{array}$ \\
\hline Policies and Guidelines & $\begin{array}{l}\text { The policies and guidelines } \\
\text { that teacher teams operate in } \\
\text { within the regulatory bodies } \\
\text { of the school. Often these } \\
\text { include both school }\end{array}$ & $\begin{array}{l}\text { In Team A, school } \\
\text { assessment documents and } \\
\text { curriculum syllabi notably } \\
\text { shaped the direction and } \\
\text { processes of the team }\end{array}$ \\
\hline
\end{tabular}




\begin{tabular}{ll}
\hline & $\begin{array}{l}\text { regulation and the greater } \\
\text { educational system }\end{array}$ \\
\hline School leadership & The contribution, support Team B identified support by \\
and investment of the school the principal in setting the & leadership team to the focus of teams, organising \\
collaborative teacher team ongoing meeting time and & participation in team \\
\end{tabular}

\section{Transformative shared purpose}

In schools, teacher teams are encouraged to complete meaningful tasks together that lead to transformative change directly related to teaching and learning (Dufour \& Fullan 2013). Studies have indicated that the focus of tasks should provide evidence of coherence between individual, team and school goals (Stoll et al. 2006, Meirink et al. 2010). In other words, a shared purpose to teamwork is important. A shared purpose was evident in all teams in this study where teams were formed based on a school identified priority of mathematics but each had the autonomy to concentrate more directly on this priority by ensuring it was meaningful to their own classroom contexts.

Having a shared purpose of professional development provides schools with an opportunity for transformative outputs beyond a single teacher or teacher team to instead whole school outputs that can positively transform all teachers and students within the school. In this way, teacher teams as an open system, both are influenced by and contribute back to the school as an organization. However, a shared purpose is only beneficial if it is transformative. Too often the work of teams is not directly aligned to the impact of actions to student learning (Popp \& Goldman 2016). It is important to ensure 
that the work of teams addresses authentic questions, challenges, understandings and solutions (Zhang et al. 2011) of the school site that are valued by school and teams collectively. For school leaders, this means ensuring that time and resources are devoted to identifying authentic purposes for teamwork derived from school priorities but conducive and relevant to developing the teaching and learning in classrooms. Additionally, the collection and examination of data to provide evidence of impact is a critical step in ensuring the investment in teachers teams is transformational.

\section{Working environment}

Environmental factors such as a lack of structures and scheduled meeting time often contribute to ineffective teamwork (Tam 2015). Similarly, this study found that both time and space affected the quality of team interactions. All teams expressed the value of frequent meeting times, preferably weekly, to ensure teamwork lead to completion of tasks during meetings and not after. As such, a dedicated meeting space conducive to team conversations, away from distractions but in close proximity to other teams working on similar tasks supported a collaborative team working environment.

\section{Policies and Guidelines}

For participants involved in this study, mandated curriculum syllabus policies had a minimal influence on their work. Instead, assessment tasks were designed more organically based on past experiences, previous assessment tasks and the sharing of ideas amongst team members. This conforms with research from Aspland et al. (2012) and Gale and Densmore (2003) who suggest that classroom teachers often disengage with policy. While teachers learning from one another through talk and sharing ideas is valuable (Hattie 2012, Many \& Sparks-Many 2015), focussing too heavily on internal 
ideas may result in work that does not fulfil mandated policy obligations. Instead, teamwork is strengthened when policy is seen as a process. To enact this, school leaders should consider how to support teacher teams with time and professional development that actively engages teachers with specific direction on interpretation and implementation procedures as a way to reduce passive engagement within policy and instead encourage empowered policy producers (Bowe et al. 1992, Ball 1994, Gale \& Densore 2003).

\section{School leadership}

The importance of leadership in supporting effective collaboration is well founded (Gumus, Bulut, \& Bellibas 2013, Szczesiul \& Huizenga 2014, Balyer et al. 2015, Vanblaere \& Devos 2016). Common in the literature is the focus on the principal, to support the collaborative culture of the school. While this study did not directly work with principals, teams explained, that in relation to team meetings, their principals set the direction, provided dedicated time and space and facilitated whole school meetings to support their professional development in teams. In this way school leadership indirectly impacted on teacher teams by creating the necessary conditions, such as routines, resources and management to support team effectiveness. This input has the potential to provide opportunities for team outputs to positively impact the teaching and learning in the school environment. It is when school leaders do not value, contribute or support teacher teams, that outputs have the potential to become less effective (Balyer, Karatas \& Alci 2015).

\section{Throughput elements}

Team facilitation, team cohesion and deep interactions between team members were identified as enabling throughputs of collaborative teacher teamwork. Each element is defined in Table 4 and elaborated on below. 
Table 4: Throughput elements of collaborative teacher teams

\begin{tabular}{|c|c|c|}
\hline $\begin{array}{l}\text { Throughput } \\
\text { Element }\end{array}$ & Definition & Example from study \\
\hline Team facilitation & $\begin{array}{l}\text { A designated team member } \\
\text { who leads team processes }\end{array}$ & $\begin{array}{l}\text { All teams had an identified } \\
\text { facilitator. Facilitators } \\
\text { provided expert guidance } \\
\text { (e.g., through offering and } \\
\text { clarifying ideas) and lead } \\
\text { interactions and discussions } \\
\text { (e.g., through questioning } \\
\text { and refocussing discussions) }\end{array}$ \\
\hline Team cohesion & $\begin{array}{l}\text { The ability of team members } \\
\text { to find ways to relate to each- } \\
\text { other's needs increasing } \\
\text { interdependence so as to } \\
\text { generate outputs }\end{array}$ & $\begin{array}{l}\text { Team A members taught the } \\
\text { same grade level and as a } \\
\text { result co-designed the same } \\
\text { output that was used by all } \\
\text { team members }\end{array}$ \\
\hline Deep interactions & $\begin{array}{l}\text { Allows members authority } \\
\text { and responsibility to solve } \\
\text { problems by involving } \\
\text { evidence-based decision } \\
\text { making and rigorous dialogue } \\
\text { that is guided by } \\
\text { organizational focus }\end{array}$ & $\begin{array}{l}\text { Teams made decisions about } \\
\text { assessment format, timing, } \\
\text { tasks and student } \\
\text { achievement levels }\end{array}$ \\
\hline
\end{tabular}




\section{Team facilitation}

Organising team meetings, leading team processes and providing expert knowledge have been identified in previous studies as important practices of team facilitation (Becuwe et al. 2016, McKenney et al. 2016). In this study expert advice and supporting team discussions contributed to both task development and team work. The team facilitator of Team A lead task development through expert guidance. She offered and clarified ideas, gave information and answered questions. Additionally, the Team leader of A and B lead through facilitation, with a particular focus on interactions and discussions. They were observed inviting participation, paraphrasing ideas and refocussing discussions. In the interviews, these team facilitators commented on their awareness of their role as facilitators and the need to carefully balance expert advice with team building processes (e.g., connecting ideas of team members). It was also evident that team members showed both trust and respect for the facilitators. For school leaders, it seems the investment of identifying, and developing team facilitators who can support high levels of team dialogue and team member trust, is crucial in the support of effective team interactions.

\section{Cohesiveness of team members}

Team members who find ways to relate to each-other's needs are more likely to be motivated to work together (Schermerhorn, Hunt \& Osborn 2002, Stoll et al. 2006). In this study, when teachers worked in the same grade level, interdependence increased. In contrast, team members who taught different grade levels needed to break into pairs or work individually to produce tasks that were appropriate for their classrooms. While team members commented that they found value in working across grade levels to develop consistency with assessment practices, there was less interdependence and task 
completion took longer to achieve. As such, similar grade and/ or curriculum groupings of teacher teams would benefit from team cohesion. School leaders, however should be cognisant of ensuring the multiple teams within the school have opportunities to crosscollaborate to share ideas and develop consistency between teams that can ultimately produce cohesive positive outcomes for the school.

\section{Deep interactions}

High leverage interactions between team members, such as data based decision making, reflective dialogue and challenging yet supportive conversations (Robutti 2016) should be enacted to ensure outputs produced by the teams are rigorous enough to improve teaching and student learning. In this study, members interacted to make decisions about assessment format, timing, tasks and student achievement levels. Findings revealed that expert knowledge and past experiences significantly impacted decisions although professional debate and problem solving amongst members was limited. An implication is that teamwork can be underpinned by sharing of ideas and resources instead of shifting pre-existing ideas, trialling new practices and changing status quo beliefs and assumptions. As such, developing team facilitators who have the skills and knowledge to facilitate site based professional development in areas such as challenging conversations, data based decision marking and monitoring the effectiveness of practices, is a key implication for schools (Salleh 2016).

\section{Output elements}

Teaching and learning products, teacher knowledge, collaborative practices and student achievement were identified as significant outputs of the study. Each of the elements is defined in Table 5 and elaborated on below. 
Table 5: Output elements of collaborative teacher teams

\begin{tabular}{|c|c|c|}
\hline Output Element & Definition & Examples from study \\
\hline $\begin{array}{l}\text { Teaching \& learning } \\
\text { products }\end{array}$ & $\begin{array}{l}\text { A resource developed that adds } \\
\text { value to teaching and learning and } \\
\text { has the capacity to benefit the } \\
\text { greater school environment }\end{array}$ & $\begin{array}{l}\text { Team A developed assessment } \\
\text { tasks that were part of a whole } \\
\text { school agreed upon process, where } \\
\text { they were saved onto the school } \\
\text { online servers so that they could be } \\
\text { shared and utilised by other teams }\end{array}$ \\
\hline Teacher knowledge & $\begin{array}{l}\text { New information and knowledge } \\
\text { developed within the dynamics of } \\
\text { the team itself in the form of } \\
\text { practical or tacit knowledge }\end{array}$ & $\begin{array}{l}\text { Teams developed new knowledge } \\
\text { in designing assessment and } \\
\text { curriculum content both within and } \\
\text { surrounding grade syllabus }\end{array}$ \\
\hline Collaborative practices & $\begin{array}{l}\text { The way members learn to work } \\
\text { productively together. This } \\
\text { includes trusting relationship, } \\
\text { professional debate, problem } \\
\text { solving, attentive listening, } \\
\text { reflection, risk taking and } \\
\text { innovation. }\end{array}$ & $\begin{array}{l}\text { All teams shared the benefit of } \\
\text { working with members in their } \\
\text { team where team members } \\
\text { developed their collaborative skills } \\
\text { in attentive listening, reflection, } \\
\text { risk taking and innovation }\end{array}$ \\
\hline Student achievement & $\begin{array}{l}\text { The team focusses on how the } \\
\text { teacher teams will improve student } \\
\text { achievement }\end{array}$ & $\begin{array}{l}\text { Students were at the centre of some } \\
\text { team's conversations where ideas } \\
\text { for assessment tasks were derived } \\
\text { from what they knew about the } \\
\text { students in their classrooms }\end{array}$ \\
\hline
\end{tabular}

\section{Teaching and Learning Products}

The generation of products forms a major part of the outputs of teamwork. While products remain responsive to the needs of the team by adding value to teaching and learning, a significant consideration in open systems is that products lead to improved 
capacity of the organization (Schermerhorn, Hunt \& Osborn 2002). In this study, it was evident that some teams considered the relationship between the product developed and how this product can support organizational capacity. For example, Team A developed assessment tasks that were part of a whole school agreed upon process where each team in the school was also developing similar products. This exemplifies how products are generated and add value to the whole school organization. Accordingly, for school leaders, the collection and access of products developed at the school site is an important consideration, however oversight to the products that teams develop should also be considered. In this way, the quality of products produced by teams is monitored to ensure their use positively impacts teaching and learning.

\section{Teacher Knowledge}

While product generation has the potential to formally document new information and knowledge, teacher knowledge developed over time cannot always be stored formally. Pfeffer and Sutton (2000) explain that products such as written procedures and documents do not suffice in recording practical or tacit knowledge. Instead, knowledge exists within the dynamics of the team itself, in stories told, trials and errors experienced, observations and modelling of and by others. In this study, many of the interactions were centred on sharing of ideas and resources resulting in increased tacit and practical knowledge. In consideration of an open system, what is important for schools is to capitalize on new knowledge as an output of teamwork by finding ways to expand the repositories of cumulatively built up teacher knowledge into organizational knowledge, beneficial to other school members. This may include, as Team A in this study explained, fortnightly meetings where all teams shared, reflected and adjusted their work ensuring ideas transferred to whole school approaches and guidelines. 


\section{Collaborative practices}

While team interactions have been discussed previously as important throughputs to teamwork, the collaborative practices team members develop by working together is also an important output useful for organizational capacity. Trusting relationships (Chatalalsingh \& Reeves 2014, Balyer et al. 2015) as well as higher level practices such as rigorous debate, problem solving and innovation are important aspects of collaborative practices (Hattie 2012, Many \& Sparks-Many 2015, Robutti, 2016). While team members in the study identified positive relationships as enablers of collaboration, professional challenge of ideas and assumptions of team members were less evident.

\section{Student achievement}

An output of collaborative teacher teams must lead to improved student achievement (Flanagan et al. 2016, Marzano et al. 2016). All teams in the study focussed on work that would directly impact on their students. While this study showed the significance of authentic team purpose to members classrooms, it did not measure the effectiveness of teamwork on student learning. Further research on the relationship between teacher teamwork and student achievement is needed.

\section{A preliminary framework for Collaborative teacher teams as an open system}

A system is a set of elements that function as a whole to achieve a purpose (Betts 1992). In the previous section, collaborative teacher teams and their dependence on certain elements associated with inputs, throughputs and outputs were discussed. Here, a preliminary descriptive framework (see Figure 1) drawn from the literature and findings of this study is presented with specific focus on how it can be useful to support site based 
professional development and how the elements are contextually responsive and require ongoing feedback and reflection.

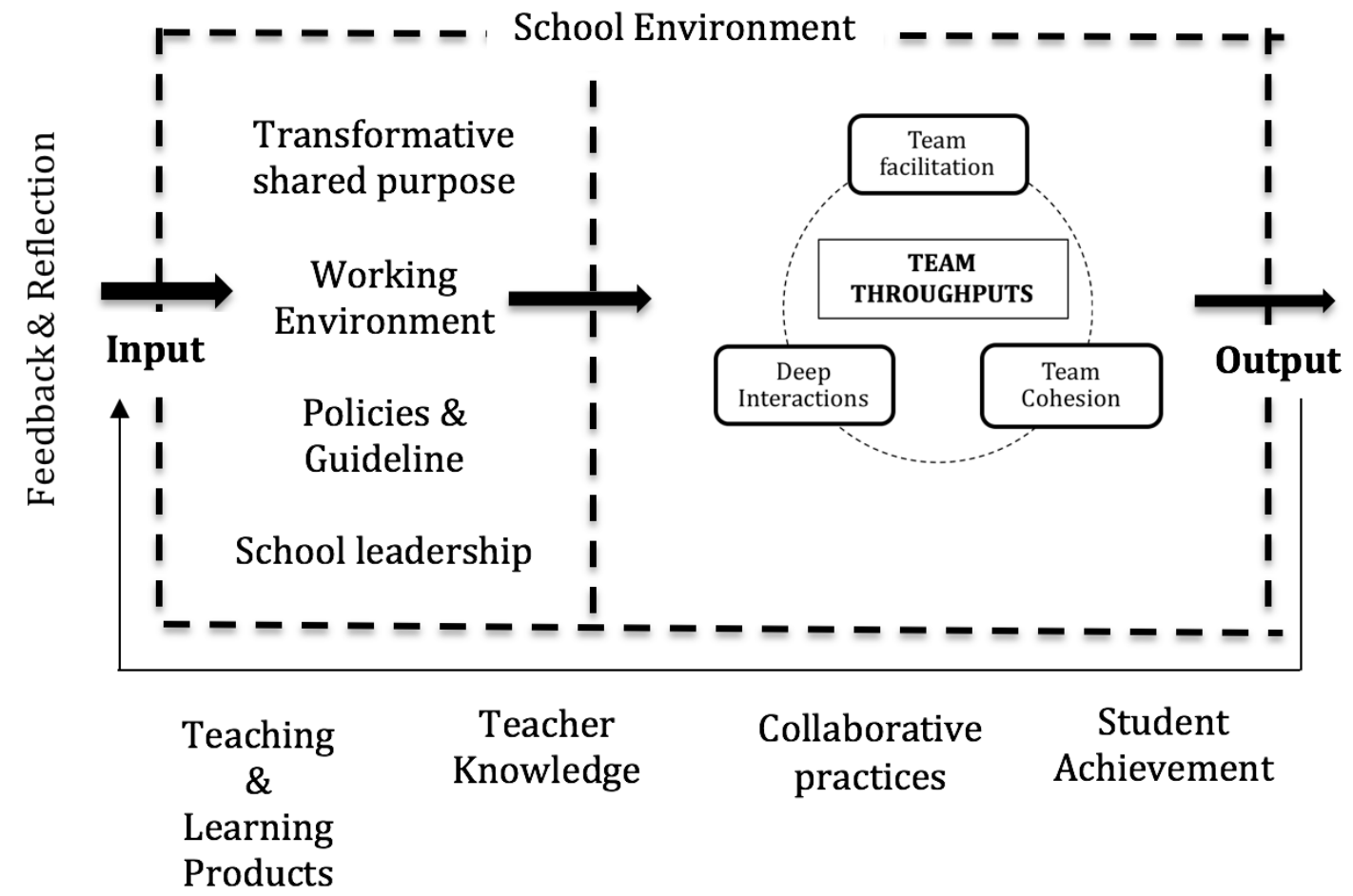

Figure 1. A preliminary framework for Collaborative teacher teams as an open system

The Collaborative teacher team as an open system preliminary framework may be useful for school leaders planning to establish or further develop teacher teams as an approach to site based professional development. To understand and support site based professional development, such as teacher teams, the system in which they operate in (Borko, 2004) and the characteristics that influence their work must be developed and understood. This framework provides school leaders with a way to analyse the various elements that influence the workings of teacher teams and consider how best to plan, develop and coordinate these in a manner that leads to successful collaborative team work that directly impacts teaching and learning. For example, in consideration of the throughput of deep interactions, developing the skill of team facilitators to shift conversations focussed on ideas and resources to critical examinations of teacher practice instead has the potential 
to develop the output of collaborative practice and teacher knowledge (Borko 2004). The framework encourages school leaders to consider the school system at multiple levels, enabling the environment in which teacher teams operate to support successful site based professional development to produce positive outputs to the school organisation.

When considering the framework to plan and develop teacher teams, an understanding that the elements are not standardised but instead are contextually responsive to the school environment is required. For example, while curriculum policies will continue to be an input in schools, they are particularly significant to teacher teams when a new curriculum syllabus is implemented. Collaborative teacher teams, as an approach to site based professional development, must be reflexive to adopt to the evolving and changing contexts of schools.

Regular reflection and feedback on the inputs, throughputs and outputs of collaborative teacher teams should be continuous. Previous studies suggest that collaborative teamwork should be conducive of ongoing reflection and monitoring in its effectiveness to teaching and learning improvement as well as team interactions and productivity (Bolam et al. 2005). This will help to ensure that the information learned from teams in the organization is adjusted, if necessary, to build more effective teamwork in the future, which may lead to greater school capacity. This reflection and feedback results in teams understanding the consequences of their actions on the school organization (Ahrweiler 2011).

\section{Limitations and recommendations for further research}

There are a number of limitations of the study. Firstly, the selection of participants, where principals volunteered their schools and then team members volunteered themselves, highlights the main limitation of this study. Voluntary participation showed a 
commitment by the principal and team members to engage with an examination of collaborative team work, which is unlikely to be universal in all schools. Noted also was that the principal's voice was not represented in data collection. As school leadership was identified as a significant input to collaborative teacher teams, future research should include principals as participants. Additionally, there was a difference in the quantity of data collected from each of the three teacher teams. As the study was not an intervention, and instead exploratory, teacher teams and the associated data collected were quite diverse, representing the unique context of each site. While this is often the nature of qualitative research in schools, it did result in an imbalance of data across teams. Finally, the exploratory nature and small sample size of the current study contributes an insider perspective of the teacher team work in context. However, findings cannot be generalized. Further research with a larger sample of schools is recommended in order to examine the 'Collaborative teacher team as an open system' preliminary framework within a wider range of school contexts.

\section{Conclusion}

Teacher teams are made up of educators with a common purpose. Their collaborative interactions on site help to develop their professional practice in order to impact student learning. The actions of teams both affect and are affected by the others in the organization. Through an open system frame, interdependence is extended to elements within the team and school environment. This study has found that the organizational context is of great importance in enabling teacher collaboration. Careful consideration to the connections and interactions of the various elements within and beyond the team is necessary to promote continuous site based professional development leading to improved teaching and learning outcomes 


\section{Disclosure statement}

No potential conflict of interest was reported by the authors.

\section{References}

Adams, M., 2016. Coaching psychology in schools: enhancing performance, development and wellbeing. London: Routledge.

Ahrweiler, P., 2011. Innovation in complex social systems. New York: Taylor \& Francis.

Armstrong, F., Belmont, B., and Verillon, A., 2000. Vive la difference? Exploring content, context, policy and change in special education in France: Developing crosscultural collaboration. In F. Armstrong, D. Armstrong, and L. Barton, eds. Inclusive education policy, contexts and comparative perspectives. London: David Fulton, 42-60.

Aspland, T., Datta, P., and Talukdar, J., 2012. Curriculum policies for students with special needs in Australia. International Journal of Special Education, 27(3), 36-44.

Ball, S., 1994. Education reform: A critical and post-structural approach. Buckingham: Open University Press.

Ball, D., and Forzani, F., 2011. Building a Common Core for Learning to Teach. American Educator, 35 (2), 17-21.

Ball, S., et al., 2011. Policy subjects and policy actors in schools: Some necessary but insufficient analyses. Discourse: Studies in the Cultural Politics Education, 32 (4), 611624. 
Balyer, A., Karatas, H., and Alci, B., 2015. School Principals' Roles in Establishing Collaborative Professional Learning Communities at Schools. In 7th World Conference on Educational Sciences, Athens: Elsevier Ltd, 1340-1337.

Bastedo, M., 2006. Open systems theory. In F. W. English eds. Encyclopaedia of educational leadership and administration. Thousand Oaks, CA: SAGE Publications, 712-712.

Betts, F., 1992. How systems thinking applies to education. Educational Leadership, 50 (3), 38-41.

Becuwe, H., et al., 2016. Teacher design teams as a strategy for professional development: The role of the facilitator. Educational Research and Evaluation, 22 (3-4), 141-154.

Bolam, R., et al., 2005. Creating and sustaining effective professional learning communities. Research Report 637. London: DfES and University of Bristol.

Borko, H., 2004. Professional Development and Teacher Learning: Mapping the Terrain. Educational Researcher, 33 (3), 3-15.

Bowe, R., Ball, S., and Gold, A., 1992. Reforming education and changing schools: Case studies in policy sociology. London: Routledge.

Brooks, C.F., 2010. Toward 'hybridised' faculty development for the twenty-first century: blending online communities of practice and face-to-face meetings in 
instructional and professional support programmes. Innovations in education and teaching international, 47 (3), 261-270.

Bryk, A., and Schneider. B., 2003. Trust in Schools: A Core Resource for School Reform. Educational Leadership, 60(6), 40-45.

Chatalalsingh, C., and Reeves, S., 2014. Leading team learning: what makes interprofessional teams learn to work well? Journal of Interprofessional Care, 28(6), 513518.

Donohoo, J., Hattie, J., and Eells, R., 2018. The Power of Collective Efficacy. Educational Leadership, 75(6), 40.

DuFour, R., et al., 2007. Learning by Doing: a handbook for Professional Communities at work. Blookington, USA: Solution Tree.

DuFour, R., and Fullan, M., 2013. Cultures built to last: systematic PLC's at Work. Bloomington, USA: Solution Tree.

Duyar, I., 2013. Multilevel analysis of teacher work attitudes The influence of principal leadership and teacher collaboration. International Journal of Educational Management, 27(7), 700-719.

Fereday, J., and Muir-Cochrane, E., 2006. Demonstrating Rigor Using Thematic Analysis: A Hybrid Approach of Inductive and Deductive Coding and Theme Development. International Journal of Qualitative Methods, 5(1), 1-11. 
Flanagan, T., et al., 2016. Transformative Collaboration: 5 commitments for Leading a Professional Learning Community. Victoria Australia: Hawker Brownlow Education.

Gale, T., and Densmore, K., 2003. Engaging teachers: Towards a radical democratic agenda for schooling. England: Open University Press.

Garza, R., Ovando., and O'Doherty, A. 2016. Aspiring School leaders' Perceptions of the Walkthrough Observations. NCPEA International Journal of Educational Leadership Preparation, 11(1).

Grima-Farrell., C, 2015. Mentoring pathways to enhancing the personal and professional development of pre-service teachers'. International Journal of Mentoring and Coaching in Education, 4, 255-268.

Gumus, S., Bulut, O., and Bellibas, S., 2013. The Relationship between Principal Leadership and Teacher Collaboration in Turkish Primary Schools: A Multilevel Analysis. Education Research and Perspectives, 40, 1-29.

Hackman, J. R., 1987. The design of work teams. In: I. Lorsch editor. Handbook of Organizational Behavior, Englewood Cliffs, NJ: Prentice-Hall, 315-342.

Harris, A., and Jones, M., 2010. Professional learning communities and system improvement. Improving Schools, 13(2), 172-181.

Harris, A., Jones, M., and Huffman, J., 2018. Teachers Leading Educational Reform: The Power of Professional Learning Communities. New York: Routledge. 
Hattie, J., 2012. Visible learning for teachers: Maxaimising impact on learning. New York: Routledge.

Hill, H., and Grossman, P., 2013. Learning from Teacher Observations: Challenges and Opportunities Posed by New Teacher Evaluation Systems. Harvard Educational Review, 83(2), 371-384.

Hipp, K., et al., 2008. Sustaining professional learning communities: Case Studies. Journal of Educational Change, 9(2), 173-195.

Hobson, A.J., et al., 2009. Mentoring Beginning Teachers: What We Know and What We Don't. Teaching and Teacher Education, 25, 207-216.

Hoegl, M., and Gemuenden, H.G., 2001. Teamwork quality and the success of innovative projects: A theoretical concept and empirical evidence. Organization Science, 12(4), 435449.

Kemmis, S., McTaggart, R., and Nixon, R., 2014. The Action Research Planner. Singapore: Springer.

Kemmis, S., et al., 2014. Changing Practices, Changing Education. Singapore: Springer Education.

Kervin, L., Mantei, J., and Lipscombe, K., 2015. The intricacies of Classroom- Based Ethnography. SAGE Research Methods (pp. 1-25). United States: Sage 
Kraft, M., Blazar, D., and Hogan, D., 2018. The effect of teacher coaching on instruction and achievement: A meta-analysis of the causal evidence. Review of Educational Research, 88(4), 547-588.

Lofthouse, R., and Thomas, U., 2017. Concerning collaboration: teachers' perspectives on working in partnerships to develop teaching practices. Professional Development in Education, 43(1), 36-56.

Many, T., and Sparks-Many, S., 2015. Leverage: Using PLCs to Promote Lasting Improvement in Schools. Thousand Oaks, CA: Corwin Press.

Marzano, R., et al., 2016. Collaborative Teams that Transform Schools. USA: Marzano Research.

McKenney, S., et al., 2016. Collaborative design of technology- enhanced learning: What can we learn from teacher talk? TechTrends, 60, 385-391.

McLaughlin, M. W., and Talbert, J. E., 2001. Professional communities and the work of high school teaching. Chicago, IL: University of Chicago Press.

Meirink, J. A., et al., 2010. Teacher learning and collaboration in innovative teams. Cambridge Journal of Education, 40(2), 161-181.

Mullen, C.A., 2000. Constructing co-mentoring partnerships: walkways we must travel. Theory into Practice. 39(1), 4-11. 
Mullen, C. A., and Hutinger, J. L., 2008. The principal's role in fostering collaborative learning communities through faculty study group development. Theory Into Practice, 47(4), 276-285.

Murphy, J., et al., 2009. The role of the principal in fostering the development of distributed leadership. School Leadership and Management, 29(2), 181-214.

Nolan, A., and Molla.,T., 2017. Teacher confidence and professional capital. Teaching and Teacher Education, 62, 10-18.

Ohlsson, J., 2013. Team learning: collective reflection processes in teacher teams. Journal of Workplace Learning, 5, 296.

Ozga, J., 1990. Policy research and policy theory: A comment on Fitz and Halpin. Journal of Education Policy, 5(4), 359-362

Pfeffer, J., and Sutton, R. I., 2000. The Knowing Doing Gap. Massachusetts: Harvard Business School of Publishing.

Popp, J., and Goldman, S., 2016. Knowledge building in teacher professional learning communities: Focus of meeting matters. Teaching and Teacher Education, 59, 347-359.

Rempe-Gillen, E, 2018. Primary school teacher expereinces in cross- phase professional development collaborations. Professional Development in Education, 44(3), 356-368. 
Robutti, O., 2016. ICME International Survey on Teachers Working and Learning through Collaboration: June 2016. ZDM: The International Journal on Mathematics Education, 48(5), 651-690.

Salleh, H., 2016. Facilitation for professional learning community conversations in Singapore, Asia Pacific Journal of Education, 36(2), 285-300.

Schermerhorn, J. R., Hunt, G. J., and Osborn, N. R., 2002. Organizational behaviour. New York: Wiley York.

Schneider, M. C., Egan, K. L., and Julian, M. W., 2013. Classroom assessment in the context of high-stakes testing. In J. H. McMillan, ed, SAGE Handbook of Research on Classroom Assessment. United States of America: SAGE Publications, 55-70.

Stoll, L., et al., 2006. Professional learning communities: A review of the literature. Journal of Educatonal Change, 7 (4), 221-258.

Stoll, L., Halbert, J., and Kaser, L., 2011. Deepening learning in school to schools networks. In C. Day, ed. International Handbook on Teacher and School Development. London: Routledge, 493-505.

Szczesiul, S., and Huizenga, J., 2014. The burden of leadership: Exploring the principal's role in teacher collaboration. Improving Schools, 17(2), 176-191. 
Tam, A. C. F., 2015. The Role of a Professional Learning Community in Teacher Change: A Perspective from Beliefs and Practices. Teachers and teaching, theory and practice, $21(1), 22-43$.

Vanblaere, B., and Devos, G., 2016. Relating school leadership to perceived professional learning community characteristics: A multilevel analysis. Teaching and Teacher Education, 57, 26-38.

Vescio, V., Ross, D., and Adams, A., 2008. A Review of Research on the Impact of Professional Learning Communities on Teaching Practices and Student Learning. Teaching and Teacher Education, 24, 80-91.

Wenger, E., 1998. Communities of practice: learning, meaning, and identity. New York, NY: Cambridge University Press.

Zhang, J., et al., 2011. Sustaining knowledge building as principle-based innovation at an elementary school. The Journal of the Learning Sciences, 20, 262-307. 